\title{
Induction of salt stress tolerance in chives by priming with $\mathrm{H}_{2} \mathrm{O}_{2}$ in hydroponic cultivation
}

\author{
Bárbara D.B. dos Santos ${ }^{1}$, Patrícia F. da Silva ${ }^{2 *}$, Rigoberto M. de Matos ${ }^{1}$, José D. Neto ${ }^{1}$, \\ Vera L.A. de Lima ${ }^{1}$, Semako I. Bonou ${ }^{1}$, Alberto S. de Melo ${ }^{3}$ and Yuri L. Melo ${ }^{3}$
}

\begin{abstract}
${ }^{1}$ Universidade Federal de Campina Grande, Unidade Acadêmica de Engenharia, CEP 58.109-970, Rua Aprígio Veloso - Bodocongó, CM block, Campina Grande - Paraíba, Brasil.

${ }^{2}$ Universidade Federal de Campina Grande, Centro de Tecnologia e Recursos Naturais, CEP 58.109-970, Rua Aprígio Veloso Bodocongó, Campina Grande - Paraíba, Brasil. "Corresponding author (patrycyafs@yahoo.com.br).

${ }^{3}$ Universidade Estadual da Paraíba, Centro de Ciências Biológicas e da Saúde, Coordenação do Programa de Pós-Graduação em Ciências Agrárias, CEP: 58429-500, Rua Baraúnas, 351 - Universitário, Campina Grande - Paraiba, Brasil.
\end{abstract}

Received: 15 December 2020; Accepted: 13 March 2021; doi:10.4067/S0718-58392021000300317

\begin{abstract}
The use of salt stress attenuators is considered an important tool to minimize the deleterious effects of salts. However, its application to chives (Allium schoenoprasum L.) has not been studied. This study aimed to evaluate the induction of salt stress tolerance in chives plants in relation to growth and enzymatic reactions, when subjected to different salinity levels of the nutrient solution, after acclimation of seeds with hydrogen peroxide $\left(\mathrm{H}_{2} \mathrm{O}_{2}\right)$ for $24 \mathrm{~h}$. The experiment was conducted in a greenhouse, where chives seeds were acclimated by $\mathrm{H}_{2} \mathrm{O}_{2}$ at concentrations of $0.0,0.15,0.30,0.45$ and $0.60 \mathrm{mmol}$. After germination, the plants were cultivated in hydroponic system with electrical conductivities of 1.0, 2.0,3.0,4.0 and $5.0 \mathrm{dS} \mathrm{m}^{-1}$. Plant height, length and number of leaves, $\mathrm{H}_{2} \mathrm{O}_{2}$ content, malondialdehyde and catalase (CAT) activity were evaluated in chives plants. The increase in the salinity of the nutrient solution up to $5 \mathrm{dS} \mathrm{m}^{-1}$ reduced by $5.88 \%, 17 \%$ and $9.63 \%$ plant height, leaf length and number of leaves, respectively. It was observed that the acclimation of chives seeds with $\mathrm{H}_{2} \mathrm{O}_{2}$ at $0.45 \mathrm{mmol} \mathrm{g}^{-1}$ fresh mass in plants that were cultivated in nutrient solution of $3.73 \mathrm{dS} \mathrm{m}^{-1}$ led to maximum CAT activity, minimizing the deleterious effects of nutrient solution salinity on plant growth.
\end{abstract}

Key words: Acclimation, Allium schoenoprasum, hydrogen peroxide, malondialdehyde, salts.

\section{INTRODUCTION}

Chives (Allium schoenoprasum L.) are a vegetable grown in different regions of the world, being very popular in Brazil, used as a condiment in the preparation of varied dishes, such as soups, meats, fish and roasts (Simões et al., 2016). Chives have anticancer, antioxidant, anti-inflammatory and antithrombotic properties (Aslam et al., 2017).

In addition to the benefits for health, this vegetable contributes to the social development of small farmers, since its cultivation uses family labor (Gama et al., 2016). However, its production in northeastern Brazil can be reduced due to rainfall irregularity. Another limiting factor is that the water from the water bodies of the region contains high levels of salts, which can reduce crop yield (Holanda et al., 2016).

The reduction in yield results, in particular, from the salts present in irrigation water, which cause limitations to agricultural production due to the osmotic effects, oxidative stress and toxicity that in extreme cases lead to plant death (Taiz et al., 2017). In addition, gas exchange is also affected due to the decrease in the osmotic potential of the nutrient solution (Dias et al., 2016).

In view of the aspects addressed, it is necessary to search for technologies adapted to the local reality. In this context, hydroponics presents itself as an alternative for the use of lower quality water, because hydroponic cultivation reduces 
the effects of salts on plants when compared to soil cultivation, due to the absence of matric potential and its state of saturation, increasing the free energy of water and facilitating its absorption by the plant (Silva Júnior et al., 2019).

Another technique that can minimize the deleterious effects of salts present in irrigation water or hydroponic solution is the acclimation of seeds with hydrogen peroxide $\left(\mathrm{H}_{2} \mathrm{O}_{2}\right)$ to induce tolerance to salt stress, because it can act as a signaling molecule (Amooaghaie and Tabatabaie, 2017), triggering mechanisms that significantly increase the levels of enzymatic and non-enzymatic antioxidants, which act against oxidative stresses (Javed et al., 2018).

Although $\mathrm{H}_{2} \mathrm{O}_{2}$ may act as a stress signal, it is not yet possible to state what are the critical levels of reactive oxygen species (ROS), mainly $\mathrm{H}_{2} \mathrm{O}_{2}$, that lead to signaling or oxidative damage (Cerny et al., 2018).

Given the relevance of the theme, the objective of this study was to evaluate the induction of salt stress tolerance in chives (Allium schoenoprasum L.) in relation to growth and enzymatic reactions, when subjected to different levels of salinity in the nutrient solution, after acclimation of seeds with hydrogen peroxide for $24 \mathrm{~h}$.

\section{MATERIALS AND METHODS}

The experiment was carried out in a greenhouse belonging to the Academic Unit of Agricultural Engineering of the Federal University of Campina Grande (UFCG), located in Campina Grande (7¹3'11” S, 35 $53^{\prime} 31^{\prime}$ ” W; 550 m a.s.1.), Paraiba, Brazil.

Inside the greenhouse, a digital thermo-hygrometer was installed to record daily maximum, mean and minimum air temperature $\left({ }^{\circ} \mathrm{C}\right)$ and relative humidity $(\%)$ throughout the chives (Allium schoenoprasum L.) cultivation cycle. During the experiment, mean values of air temperature and relative humidity were $24{ }^{\circ} \mathrm{C}$ and $72 \%$, respectively.

The experimental design was randomized blocks, analyzed in a $5 \times 5$ factorial scheme, with 3 replicates, totaling 75 experimental units. The experimental unit consisted of three plants, spaced by $0.20 \mathrm{~m}$ within each hydroponic PVC profile, distributed on five benches, totaling 225 plants.

The hydroponic system used was composed of 15 PVC tubes, nutrient film technique (NFT type), low-cost, modified according to the methodology of Silva Júnior et al. (2019), solution flows three times a day, at $4 \mathrm{~h}$ interval. During the night, there was no circulation of the nutrient solution, since the coconut fiber used as a substrate provided retention without impairing the development of plants, this procedure was used by Silva Júnior et al. (2019).

Two plants were left as border, the first one and the last one inside the PVC pipe. The treatments were arranged in a factorial scheme with split plots corresponding to five levels of salinity in the nutrient solution as the main plot (S1-S5: 1.0, 2.0, 3.0, 4.0 and $5.0 \mathrm{dS} \mathrm{m}^{-1}$, respectively, at $25^{\circ} \mathrm{C}$ ) and, as the subplots, five concentrations of hydrogen peroxide $\left(\mathrm{H}_{2} \mathrm{O}_{2} ; 0.0,0.15,0.30,0.45\right.$ and $\left.0.60 \mathrm{mmol}\right)$ used as priming in chives seeds.

Seeds were soaked in $40 \mathrm{~mL} \mathrm{H}_{2} \mathrm{O}_{2}$ solution for $24 \mathrm{~h}$. Seeds of chives 'Todo Ano Evergreen - Nebuka' were used because it is one of the most cultivated in the Brazilian semi-arid region. After acclimation (priming), sowing was carried out in germination trays filled with commercial substrate (processed barks, expanded vermiculite, processed turf and granulated charcoal, Plantmax), which were irrigated twice a day and kept in a greenhouse.

When seedlings were $15 \mathrm{~d}$ old, they were transplanted into the hydroponic system, placed in $180 \mathrm{~mL}$ plastic cups, perforated on the sides and bottom, filled with coconut fiber as a support substrate, and placed within the hydroponic profiles, whose standard nutrient solution $\left(0.9 \mathrm{dS} \mathrm{m}^{-1}\right)$ for all salinity levels followed the recommendations of Furlani et al. (1999) for leafy vegetables. For the solution to reach the salinity levels recommended in this study, $\mathrm{NaCl}$ was added, following Equation 1, according to Richards (1954):

$$
\mathrm{C}=640 \times \mathrm{ECs}
$$

where $\mathrm{C}$ is concentration of the salt in the solution $\left(\mathrm{mg} \mathrm{L}^{-1}\right)$, ECs is electrical conductivity of the solution $\left(0.9 \mathrm{dS} \mathrm{m}^{-1}\right)$ and 640 is the correction factor of $\mathrm{mS} \mathrm{cm} \mathrm{cm}^{-1}$ to $\mathrm{mg} \mathrm{L}^{-1}$.

At $90 \mathrm{~d}$ after sowing, growth variables were evaluated: plant height $(\mathrm{PH})$ measured with a graduated ruler $(\mathrm{cm})$ from the plant collar region to the apex of the main stem; number of leaves (NL) by direct counting; and leaf length (LL) with a graduated ruler $(\mathrm{cm})$.

For biochemical evaluation, lipid peroxidation was determined by quantifying thiobarbituric acid reactive species (TBARS), as described by Cakmak and Horst (1991) with some adaptations, that is, about $100 \mathrm{mg}$ fresh mass (FM) were macerated with $2 \mathrm{~mL} 0.1 \%$ trichloroacetic acid (TCA). Aliquots were composed by the reaction of $0.5 \%(\mathrm{w} / \mathrm{v}$ ) thiobarbituric acid (TBA) and $10 \%(w / v)$ TCA and incubated at $90{ }^{\circ} \mathrm{C}$ for $40 \mathrm{~min}$, with interruption of the reaction by rapid 
cooling in an ice bath. The extracts were centrifuged again, for bleaching and ensuring absence of interfering agents. The absorbance of the sample was determined at $532 \mathrm{~nm}$, in triplicate, and to obtain the values of net absorbance, the value was subtracted from the nonspecific absorbance at $600 \mathrm{~nm}$. Lipid peroxidation by malondialdehyde (MDA) quantification was expressed in nmol MDA g ${ }^{-1} \mathrm{FM}$.

Catalase (CAT) activity was quantified according to Cakmak and Horst (1991) with adaptations. Aliquots of $0.15 \mathrm{~mL}$ enzyme extract were added; CAT activity was determined by spectrophotometry through the reduction in the absorbance at $240 \mathrm{~nm}$ for $1 \mathrm{~min}$, monitored by $\mathrm{H}_{2} \mathrm{O}_{2}$ consumption, in triplicate. One unit of CAT activity was defined as the degradation of $1 \mu \mathrm{M} \mathrm{H}_{2} \mathrm{O}_{2}$ for 1 min.

The molar extinction coefficient $(\varepsilon)$ used in the calculations for this enzyme was $39.4 \mathrm{mM}^{-1} \mathrm{~cm}^{-1}$, and expressed as mmol $\mathrm{H}_{2} \mathrm{O}_{2} \min ^{-1} \mathrm{~g}^{-1} \mathrm{FM}$.

The content of $\mathrm{H}_{2} \mathrm{O}_{2}$ in plant tissue was determined according to the methodology of Velikova et al. (2000). About $500 \mathrm{mg}$ frozen fresh material were macerated in acidic solution composed of $2 \mathrm{~mL} \mathrm{TCA}$ at $0.1 \%(\mathrm{w} / \mathrm{v})$ and centrifuged at $10000 \mathrm{rpm}$ for $10 \mathrm{~min}$ at $4{ }^{\circ} \mathrm{C}$, in test tubes containing potassium phosphate buffer at $10 \mathrm{mM}(\mathrm{pH} 7.0)$ and potassium iodide. Subsequently, $\mathrm{H}_{2} \mathrm{O}_{2}$ concentration was measured at $390 \mathrm{~nm}$ absorbance, in triplicate, and the $\mathrm{H}_{2} \mathrm{O}_{2}$ content was calculated by a standard curve of $\mathrm{H}_{2} \mathrm{O}_{2}$ previously established, expressed in $\mu \mathrm{mol} \mathrm{g} \mathrm{g}^{-1} \mathrm{FM}$.

Data that showed significant effects of treatments were described by linear and quadratic polynomial regression (individual factors and interaction between factors) and by the response surface model (in the case of interaction between factors).

The results of the interaction between factors were presented in the form of response surface $\left(z=a+b x+c x^{2}+d y\right.$ $\left.+e^{2}\right)$ only for equations with graphical fits with regression coefficient $\left(R^{2}\right)$ greater than 0.60 . For lower $R^{2}$ values in the response surface model, the interactions were represented by linear and quadratic polynomial regression.

Statistical analyses (Shapiro-Wilk and F test) were performed using the statistical program Sisvar version 5.6 (Ferreira, 2014). Table Curve 3D software (Silva et al., 2019) was used to fit the response surface models.

\section{RESULTS AND DISCUSSION}

The summary of ANOVA for plant height (PH), number of leaves (NL) and leaf length (LL) of chives plants subjected to different levels of salinity in the nutrient solution after acclimation of seeds with $\mathrm{H}_{2} \mathrm{O}_{2}$ is shown in Table 1 .

It can be observed that the different salinity levels of the nutrient solution significantly affected PH, NL and LL at $1 \%$ probability level by the $\mathrm{F}$ test. Priming with $\mathrm{H}_{2} \mathrm{O}_{2}$ did not significantly influence these variables. It was also verified that the interaction between salinity levels (SL) and $\mathrm{H}_{2} \mathrm{O}_{2}$ concentrations (HPC) (SL $\times$ HPC) had no effect on PH, NL and LL (Table 1).

The increase in nutrient solution salinity negatively affected $\mathrm{PH}$, where the maximum $(55.1 \mathrm{~cm})$ was obtained with $1 \mathrm{dS} \mathrm{m} ~^{-1}$. The maximum salinity studied $\left(5 \mathrm{dS} \mathrm{m}^{-1}\right)$ caused a 5.88\% reduction in PH compared to the lowest SL in the nutrient solution, and the reduction per unit increase of salinity was $0.63 \%$ (Figure 1A). This reduction can possibly be

Table 1. Summary of ANOVA and means for plant height (PH), number of leaves (NL) and leaf length (LL) of chives plants subjected to different levels of salinity in the nutrient solution after acclimation of seeds at different concentrations of hydrogen peroxide $\left(\mathrm{H}_{2} \mathrm{O}_{2}\right)$.

\begin{tabular}{lcccc}
\hline & & \multicolumn{3}{c}{ Mean squares } \\
\cline { 3 - 5 } Sources of variation & DF & $\mathrm{PH}$ & $\mathrm{NL}$ & $\mathrm{LL}$ \\
\hline & & $\mathrm{cm}$ & $\mathrm{cm}$ \\
Salinity levels (SL) & 4 & $89.07^{* *}$ & $2.02^{* *}$ & $213.31^{* *}$ \\
$\mathrm{H}_{2} \mathrm{O}_{2}$ concentrations (HPC) & 4 & $16.34 \mathrm{~ns}$ & $0.35 \mathrm{~ns}$ & $13.66 \mathrm{~ns}$ \\
Interaction SL $\times$ HPC & 16 & $18.12 \mathrm{~ns}$ & $0.19 \mathrm{~ns}$ & $20.00 \mathrm{~ns}$ \\
Block & - & 7.14 & 0.19 & 12.19 \\
Residual & - & 15.93 & 0.28 & 16.64 \\
Overall mean & - & 53.91 & 4.90 & 35.40 \\
$\mathrm{CV}, 1 \%$ & - & 5.54 & 9.35 & 9.97 \\
$\mathrm{CV}, 2 \%$ & - & 7.40 & 10.84 & 11.52 \\
\hline
\end{tabular}

*,**Significant at $5 \%$ and $1 \%$ probability level by $\mathrm{F}$ test, respectively; ns: nonsignificant. 
Figure 1. Means of plant height (A), number of leaves (B) and leaf length (C) of chives plants at $90 \mathrm{~d}$ after planting as a function of the different salinity levels of the hydroponic solution.

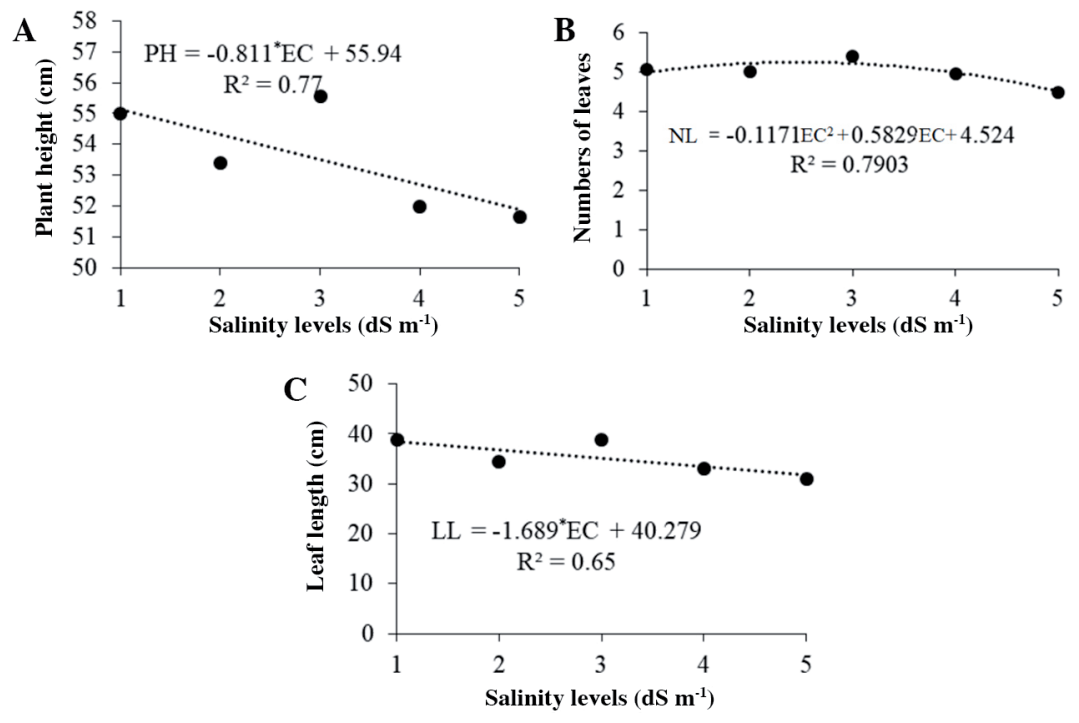

explained by the decrease in the plant's energy consumption for the synthesis of osmotically active organic compounds necessary for compartmentalization processes in the regulation of the transport of ions that influence plant growth and development (Liu and Jiang, 2015).

Silva Júnior et al. (2019), when studying chives grown in hydroponic system with different SL in the nutrient solution (at different circulation frequencies), also observed reductions in $\mathrm{PH}$, regardless of the frequencies of circulation of the evaluated solution, corroborating the data obtained in this study.

Paulus et al. (2012), evaluating lettuce cultivation in nutrient film technique (NFT) hydroponic system with the use of saline water to prepare the nutrient solution and replace the daily evapotranspired depth, observed that the increase in water salinity linearly reduced lettuce growth. The reduction in PH can be attributed to stomatal closure, gas exchange reduction, as a result of a decrease in the absorption of water and nutrients by plants, which results in a reduction in growth (Taiz et al., 2017).

The mathematical model that best fitted to NL data was quadratic (Figure 1B), and the maximum was reached at 2.48 $\mathrm{dS} \mathrm{m}{ }^{-1}$, corresponding to approximately five leaves. The reduction in this variable was equal to $9.62 \%$ between the nutrient solution SL that led to maximum NL and the highest level studied.

This result is similar to those found by Silva et al. (2014), who studied the initial growth of A. fistulosum under different levels of irrigation water salinity under soil conditions and obtained the highest NL using irrigation water with salinity of $2.1 \mathrm{dS} \mathrm{m}^{-1}$, with a production of seven leaves per plant. It can be noted that, although the experiments were conducted in soil and hydroponic environments, SL that led to maximum NL were similar.

Oliveira et al. (2013), studying the cultivation of arugula in a semi-hydroponic system with coconut fiber under different $\mathrm{SL}$ in the nutrient solutions, verified a reduction in NL as salinity increased. The reduction in NL can be attributed to the mechanisms of adaptation of the plant to salt stress, reducing the transpiring surface, aiming at reducing water loss and maintaining high water potential in the plant (Nobre et al., 2014).

For leaf length (LL) at $90 \mathrm{~d}$ of cultivation (Figure 1C), the model that best fitted was linear. From nutrient solution salinity of $1 \mathrm{dS} \mathrm{m}^{-1}$, LL decreased by $4.12 \%$ per unit increase in salinity, and the difference between the highest and lowest SL was $17 \%$.

The reduction in plant development, that is, reduction in processes involving cell division in plants under salt stress, can be attributed to changes in the allocation of photoassimilates (Taiz et al., 2017), due to the increase in energy consumption processes, such as osmotic adjustment and active transport of ions resulting from excess salts in the plant, leading to significant reductions in cell differentiation and affecting plant growth. 
The summary of ANOVA for $\mathrm{H}_{2} \mathrm{O}_{2}$, CAT and lipid peroxidation (LP) of chives plants under different SL of nutrient solution after acclimation of seeds in $\mathrm{H}_{2} \mathrm{O}_{2}$ for $24 \mathrm{~h}$ is shown in Table 2. There was a significant effect of SL of the nutrient solution at $1 \%$ probability level by the F test for HPC in leaves, CAT and LP determined by MDA quantification (Table 2).

The $\mathrm{H}_{2} \mathrm{O}_{2}$ concentrations used in seed acclimation caused significant effect at $1 \%$ probability level on CAT and LP. There was also an effect of the interaction between SL of the nutrient solution and $\mathrm{H}_{2} \mathrm{O}_{2}$ concentrations used in seed acclimation at $1 \%$ probability level on HPC in leaves, CAT and LP quantified based on MDA concentration (Table 2).

The HPC in plant tissue $\left(\mathrm{H}_{2} \mathrm{O}_{2}\right.$ in the plant) as a function of the interaction between SL of nutrient solution and $\mathrm{H}_{2} \mathrm{O}_{2}$ concentrations applied to the soaking of chives seeds at $90 \mathrm{~d}$ after sowing was modeled by the response surface $\left(\mathrm{R}^{2}=0.62\right)$ (Figure 2). It can be verified that HPC in plant tissue increased progressively with the salinity of the nutrient solution.

It can also be noted that plants grown at $1 \mathrm{dS} \mathrm{m}^{-1}$, whose seeds were acclimated by $\mathrm{H}_{2} \mathrm{O}_{2}(0.60 \mathrm{mmol})$, showed higher $\mathrm{HPC}$ in their tissue. On the other hand, plants that were subjected to the highest $\mathrm{SL}$ of nutrient solution, $5 \mathrm{dS} \mathrm{m}^{-1}$, whose seeds were not acclimated $\left(0.0 \mathrm{mmol} \mathrm{H}_{2} \mathrm{O}_{2}\right)$ had lower production of $\mathrm{H}_{2} \mathrm{O}_{2}$ in plant tissue (Figure 2).

It is observed that, when chives were subjected to the highest SL in the nutrient solution $\left(5 \mathrm{dS} \mathrm{m}^{-1}\right)$ after being acclimated in $\mathrm{H}_{2} \mathrm{O}_{2}\left(0.60 \mathrm{mmol}\right.$ ), the HPC in their tissue was $0.0804 \mathrm{mmol} \mathrm{g}^{-1} \mathrm{FM}$ (Figure 2), which is the highest HPC found among the studied treatments.

These results differ from those found by Sun et al. (2016), who studied the mode of action of the exogenous application of $\mathrm{H}_{2} \mathrm{O}_{2}$ in cucumber crop subjected to environmental stress and observed that plants sprayed with $\mathrm{H}_{2} \mathrm{O}_{2}$ obtained lower HPC in their tissue compared to those that were not sprayed.

Table 2. Summary of the ANOVA and means for hydrogen peroxide $\left(\mathrm{H}_{2} \mathrm{O}_{2}\right)$, catalase (CAT) and lipid peroxidation (LP) in chives plants grown in different saline solutions in hydroponic system after $90 \mathrm{~d}$ of cultivation.

\begin{tabular}{lcccc}
\hline & & \multicolumn{3}{c}{ Mean squares } \\
\cline { 3 - 5 } Sources of variation & $\mathrm{DF}$ & $\mathrm{H}_{2} \mathrm{O}_{2}$ & $\mathrm{CAT}$ & $\mathrm{LP}$ \\
\hline & & $\mathrm{mmol} \mathrm{g}^{-1} \mathrm{FM}$ & $\mathrm{mmol} \mathrm{H}_{2} \mathrm{O}_{2} \mathrm{~min}^{-1} \mathrm{~g}^{-1} \mathrm{FM}$ & $\mathrm{mmol} \mathrm{g}^{-1} \mathrm{FM}$ \\
Salinity levels (SL) & 4 & $0.040312^{* *}$ & $0.001130^{* *}$ & $2.756767^{* *}$ \\
$\mathrm{H}_{2} \mathrm{O}_{2}$ concentrations (HPC) & 4 & $0.001651 \mathrm{~ns}$ & $0.001231^{* *}$ & $15.618786^{* *}$ \\
Interaction SL $\times \mathrm{HPC}$ & 16 & $0.007797^{* *}$ & $0.001265^{* *}$ & $5.324301^{* *}$ \\
Block & 2 & $0.001498 \mathrm{~ns}$ & $0.000034 \mathrm{~ns}$ & $0.003385 \mathrm{~ns}$ \\
Residual & - & 0.000717 & 0.000135 & 0.134325 \\
Overall mean & - & 0.1410872 & 0.0352533 & 5.5965591 \\
$\mathrm{CV}, 1 \%$ & - & 18.98 & 32.95 & 6.55 \\
$\mathrm{CV}, 2 \%$ & - & 20.01 & 23.22 & 7.35 \\
\hline
\end{tabular}

*,**Significant at $5 \%$ and $1 \%$ probability level by $\mathrm{F}$ test, respectively; ns: nonsignificant.

Figure 2. Hydrogen peroxide $\left(\mathrm{H}_{2} \mathrm{O}_{2}\right)$ content in chives leaves grown in nutrient solutions with different levels of salinity (SL) in hydroponic system and different $\mathrm{H}_{2} \mathrm{O}_{2}$ concentrations (HPC) after $90 \mathrm{~d}$ of cultivation.

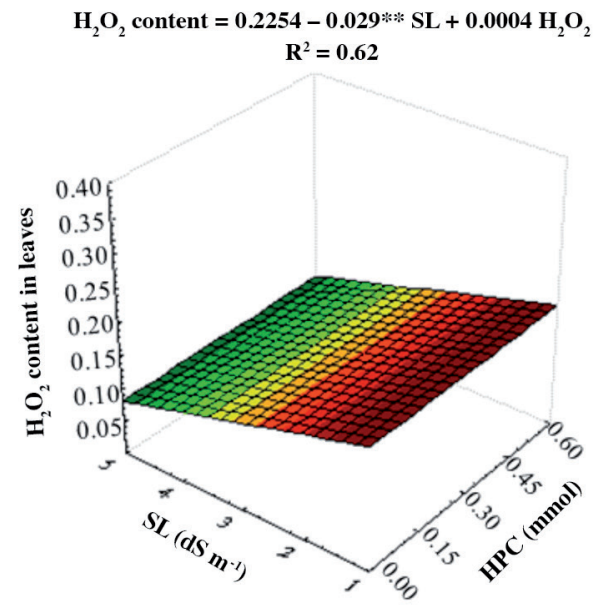


$\mathrm{H}_{2} \mathrm{O}_{2}$ in plant tissue, when at low concentrations, can perform functions as an enzymatic activator that will aid in the acclimation to stress, functioning as a signaling molecule in plants under biotic and abiotic stresses, acting on stomatal opening and closure, tolerance to oxygen deficiency, senescence, photosynthesis and cell cycle control (Cerny et al., 2018).

Thus, it can be noted that the accumulation of $\mathrm{H}_{2} \mathrm{O}_{2}$ in plant tissue under salt stress conditions triggered the mechanisms that significantly increase the contents of enzymatic and non-enzymatic antioxidants, which act against the stress caused by nutrient solution salinity (Javed et al., 2018).

Thus, it can be inferred that, as there was accumulation of $\mathrm{H}_{2} \mathrm{O}_{2}$ at all SL of nutrient solution, the use of $\mathrm{H}_{2} \mathrm{O}_{2}$ in seed acclimation may have induced tolerance in chives. As a result, no severe effects were observed on the characteristics linked to plant growth.

Hajivar and Zare-Bavani (2019), evaluating the effects of $\mathrm{H}_{2} \mathrm{O}_{2}$ and nitric oxide (NO) application to minimize damage caused by salt stress $\left(\mathrm{NaCl}\right.$ at $0,2.5,5.0$ and $\left.10.0 \mathrm{dS} \mathrm{m}^{-1}\right)$ in tomato, verified that the application of both $\mathrm{H}_{2} \mathrm{O}_{2}$ and $\mathrm{NO}$ attenuated salt stress and increased photosynthetic activity, leading to an increase in plant growth under stress conditions.

Besides acting as a signaling molecule, changes in HPC in plant cells can be an indicator of the structural integrity of the membrane in plants subjected to environmental stress (Shahid et al., 2018), because membranes are generally the first target of abiotic stresses.

At high levels of reactive oxygen species (ROS) in cells, oxidative stress occurs, resulting in the production of lipidderived radicals (Rossatto et al., 2017). The main product derived from peroxidation is MDA, which causes membrane deterioration during stress (Kumar et al., 2018).

For LP, it was observed that seeds that were not acclimated with $\mathrm{H}_{2} \mathrm{O}_{2}(0.0 \mathrm{mmol})$ when subjected to $5 \mathrm{dS} \mathrm{m}^{-1}$ in the nutrient solution showed greater damage to the membrane with peroxidation on the order of 6.64 mmol MDA g ${ }^{-1} \mathrm{FM}$ (Figure 3). This is because, under stress conditions, there is an increase in the production of ROS, resulting in electrolyte leakage, which results in membrane damage. Similar results were obtained by Khan et al. (2015), who observed that the percentage of electrolyte leakage was higher as the SL in nutrient solutions increased compared to plants that were not subjected to salt stress.

Gohari et al. (2019), evaluating the effects of the interaction between $\mathrm{H}_{2} \mathrm{O}_{2}$ and sodium nitroprusside used as priming to mitigate salt stress in basil (Ocimum basilicum), found that plant acclimation minimized cell damage, with significant reductions in MDA content under saline conditions, which were higher when compared to plants that did not receive priming. These authors observed the relationship between salinity and LP, and found that plants irrigated with the saline nutrient solution of $5 \mathrm{dS} \mathrm{m}^{-1}$ showed a significant increase in MDA content compared to the control.

Figure 3. Level of lipid peroxidation (LP) in the leaves of chives grown in nutrient solutions with different salinity levels (SL) in hydroponic system and different hydrogen peroxide $\left(\mathrm{H}_{2} \mathrm{O}_{2}\right)$ concentrations (HPC) after $90 \mathrm{~d}$ of cultivation.

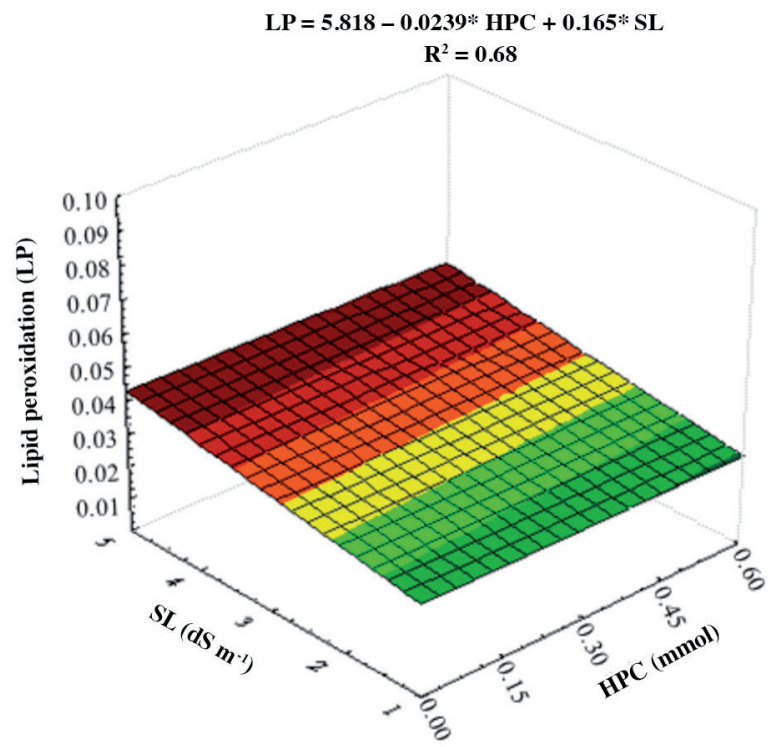


Tayebi-Meigooni et al. (2019), working with Chinese kale (Brassica oleracea L. var. alboglabra (L.H. Bailey) Musil) cultivated in hydroponic system with saline nutrient solutions at $0.0,2.5,5.0,7.5$ and $10 \mathrm{dS} \mathrm{m}^{-1}$, verified that the increase in salinity causes an increase in HPC and LP in plant tissue.

Other authors have also found that salt stress increases the contents of $\mathrm{H}_{2} \mathrm{O}_{2}$ and MDA (Daneshmand et al., 2010). This finding corroborates the data obtained in the present study, reaffirming that the increase in salinity of the nutrient solution can cause salt stress in plants. However, when plants are acclimated in particular using $\mathrm{H}_{2} \mathrm{O}_{2}$ as priming, they can trigger reactions that promote tolerance to the stress caused by salts present in the cultivation system.

When determining CAT activity as a function of the different salinity levels of the nutrient solution associated with the acclimation of seeds in $\mathrm{H}_{2} \mathrm{O}_{2}$ (Figure 4), it was noted that the maximum production of the enzyme occurred at $3.75 \mathrm{dS} \mathrm{m}^{-1}$ in the nutrient solution when seeds were acclimated with $0.45 \mathrm{mmol}_{2} \mathrm{O}_{2}$, with the maximum production of the enzyme obtained at $25.21 \mathrm{mmol} \mathrm{H}_{2} \mathrm{O}_{2} \mathrm{~min}^{-1} \mathrm{~g}^{-1} \mathrm{FM}$ (Figure 4).

Similar results were found by El-Banna and Abdelaal (2018), studying the effects of durations of immersion in $\mathrm{H}_{2} \mathrm{O}_{2}$ ( 1 and $2 \mathrm{~h}$ ) on the roots of strawberry grown in hydroponic units with saline nutrient solutions at $0.0,3.4$ and $6.8 \mathrm{dS} \mathrm{m}^{-1}$. These authors observed that root immersion for $1 \mathrm{~h}$ resulted in increased growth rates and photosynthetic pigment content, reduction in electrolyte leakage, and increased enzyme activity, including CAT, compared to plants immersed in distilled water, mitigating the effects of salinity.

Tayebi-Meigooni et al. (2019), studying Chinese kale grown in a hydroponic system under different salinities of nutrient solution, state that the increase in salt stress increased the activity of CAT. It was also reported by Freitas et al. (2019), who evaluated lettuce (Lactuca sativa L.) cultivated in hydroponic system with saline nutrient solutions at 0 and $4.0 \mathrm{dS} \mathrm{m}^{-1} \mathrm{NaCl}$ with three levels of foliar fertilization $\left(0.0,1.5\right.$ and $\left.3.0 \mathrm{~g} \mathrm{~L}^{-1}\right)$ and observed that CAT activity increased as salinity increased. It is still possible to state that this enzyme acts in mechanisms of the induction of salinity tolerance.

This enzyme is related to the activity of a complex antioxidant system whose function is to protect cells from damage caused by ROS (Rossatto et al., 2017). Through the activity of CAT, there is a decrease in the concentration of $\mathrm{H}_{2} \mathrm{O}_{2}$ and mitigation of LP in plant cells (Chen et al., 2016). The ability of a plant to tolerate salinity may be related to the balance between the production of ROS and the activation of its antioxidant defense system.

According to Gammoudi et al. (2020), acclimation with $\mathrm{H}_{2} \mathrm{O}_{2}$ modulates the activities of the enzymatic system, regulating the transcription levels of the corresponding genes, reducing oxidative stress damage and increasing salinity tolerance.

Figure 4. Catalase enzyme (CAT) activity in the leaves of chives grown in nutrient solutions with different salinity levels (SL) in hydroponic system and different hydrogen peroxide $\left(\mathrm{H}_{2} \mathrm{O}_{2}\right)$ concentrations (HPC) after $90 \mathrm{~d}$ of cultivation.

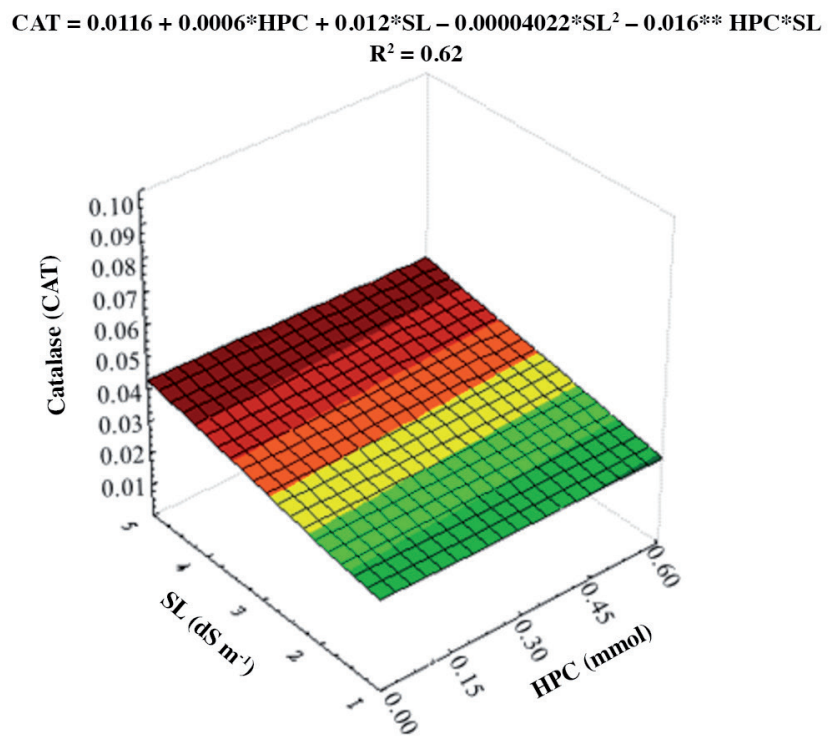




\section{CONCLUSIONS}

The use of hydrogen peroxide as priming in chives seeds induced plant tolerance to salt stress, minimizing the deleterious effects of nutrient solution salinity on growth. Acclimation of chives seeds with hydrogen peroxide at $0.45 \mathrm{mmol}$ in plants grown in nutrient solution with salinity of $3.73 \mathrm{dS} \mathrm{m}^{-1}$ led to maximum activity of the catalase enzyme, reducing the severity of the environmental stress.

\section{REFERENCES}

Amooaghaie, R., and Tabatabaie, F. 2017. Osmopriming-induced salt tolerance during seed germination of alfalfa most likely mediates through $\mathrm{H}_{2} \mathrm{O}_{2}$ signaling and upregulation of heme oxygenase. Protoplasma 3:1791-1803. doi.org/10.1007/s00709-016-1069-5.

Aslam, Z., Akhtar, S., Imran, M., Nadeem, M., Gilani, S., Elnashar, M., et al. 2017. Antioxidant activity, anti-inflammatory activities, anti-cancer and chemical composition of spring onion (Allium fistolisum) extracts. Research Journal of Pharmaceutical, Biological and Chemical Sciences 8:1880-1890.

Cakmak, I., and Horst, W.J. 1991. Effect of aluminum on lipid-peroxidation, superoxidedismutase, catalase and peroxidase activities in root tips of soybean (Glycine max). Physiologia Plantarum 83:463-468. https//doi.org/10.1111/j.1399-3054.1991. tb00121.x.

Cerny, M., Habánová, H., Berka, M., Luklová, M., and Brzobohaty, B. 2018. Hydrogen peroxide: Its role in plant biology and crosstalk with signalling networks. International Journal of Molecular Sciences 19(9):2812. doi:10.3390/ijms19092812.

Chen, D., Wang, S., Cao, B., Cao, D., Leng, G., Li, H., et al. 2016. Genotypic variation in growth and physiological response to drought stress and re-watering reveals the critical role of recovery in drought adaptation in maize seedlings. Frontiers in Plant Science 6:1241. doi:10.3389/fpls.2015.01241.

Daneshmand, F., Arvin, M.J., and Kalantari, K.M. 2010. Physiological responses to $\mathrm{NaCl}$ stress in three wild species of potato in vitro. Acta Physiologiae Plantarum 32:91-101. doi:10.1007/s11738-009-0384-2.

Dias, N.D., Blanco, F.F., Souza, E.R., Ferreira, J.F.S., Sousa Neto, O.N., e Queiroz, I.S.R. 2016. Efeitos dos sais na planta e tolerância das culturas à salinidade. p. 151-161. In Gheyi, H.R., Dias, N.S., de Lacerda, C.F., e Gomes Filho, E. (eds.) Manejo da salinidade na agricultura: Estudos Básicos e Aplicados. 2a ed. Instituto Nacional de Ciencia e Tecnologia em Salinidade (INCTSal), Fortaleza, Brasil.

El-Banna, M.F., and Abdelaal, K.A.A. 2018. Response of strawberry plants grown in the hydroponic system to pretreatment with $\mathrm{H}_{2} \mathrm{O}_{2}$ before exposure to salinity stress. Journal Plant Production 9:989-1001. doi:10.21608/JPP.2018.36617.

Ferreira, D.F. 2014. Sisvar. A guide for its bootstrap procedures in multiple comparisons, Ciência e Agrotecnologia 38:109-112. doi:10.1590/S1413-70542014000200001.

Freitas, W.E.S., Oliveira, A.B., Mesquita, R.O., Carvalho, H.H., Prisco, J.T., and Gomes-Filho, E. 2019. Sulfur-induced salinity tolerance in lettuce is due to a better $\mathrm{P}$ and $\mathrm{K}$ uptake, lower $\mathrm{Na} / \mathrm{K}$ ratio and an efficient antioxidative defense system. Scientia Horticulturae 275:1-11. doi:10.1016/j.scienta.2019.108764.

Furlani, P.R., Silveira, L.C.P., Bolonhezi, D., e Faquin, V. 1999. Cultivo hidropônico de plantas. Boletim Técnico IAC N 180. 52 p. Instituto Agronômico (IAC), Campinas, São Paulo, Brasil.

Gama, G.O., Souza, T.C., e Quevedo, L.F. 2016. Avaliação do desenvolvimento de mudas de cebolinha 'todo ano' produzidas em três tipos de substratos comerciais na região de dourados-MS. Revista Eletrônica da Faculdade de Ciências Exatas e da Terra Produção/Construção e Tecnologia 5:36-42. doi:10.15 809/irriga.2019v24n3p645-661.

Gammoudi, N., Karmous, I.,Zerria, K., Loumerem, M., Ferchich, A., and Nagaz, K. 2020. Efficiency of pepper seed invigoration through hydrogen peroxide priming to improve in vitro salt and drought stress tolerance. Horticulture, Environment, and Biotechnology 61:703-714. https://doi.org/10.1007/s13580-020-00260-8.

Gohari, G., Alavi, Z., Esfandiari, E., Panahirad, S., Hajihoseinlou, S., and Fotopoulos, V. 2019. Interaction between hydrogen peroxide and sodium nitroprusside after chemical initiation of Ocimum basilicum L. against salt stress. Physiologia Plantarum 168:361-373. doi:10.1111/ppl.12985.

Hajivar, B., and Zare-Bavani, M.R. 2019. Alleviation of salinity stress by hydrogen peroxide and nitric oxide in tomato plants. Advances in Horticulture Science 33:409-416. doi:10.13128/ahs-24335.

Holanda, J.S. de, Amorim, J.R.A., Neto, M.F., Holanda, A.C., and Sá, F.V.S. 2016. Qualidade da água para irrigação. p. 35-50. In Gheyi, H.R., Dias, N.S., de Lacerda, C.F., e Gomes Filho, E. (eds.) Manejo da salinidade na agricultura: Estudos básicos e aplicados. $2^{a}$ ed. Instituto Nacional de Ciência e Tecnologia em Salinidade (INCTSal), Fortaleza, Brasil.

Javed, R., Yücesan, B., and Gurel, E. 2018. Hydrogen peroxide-induced steviol glycosides accumulation and enhancement of antioxidant activities in leaf tissues of Stevia rebaudiana Bertoni. Sugar Tech 20:100-104. https://doi.org/10.1007/s12355017-0521-y. 
Khan, T.A., Yusuf, M., and Fariduddin, Q. 2015. Seed treatment with $\mathrm{H}_{2} \mathrm{O}_{2}$ modifies net photosynthetic rate and antioxidant system in mung bean (Vigna radiata L. Wilczek) plants. Israel Journal of Plant Sciences 62(3):167-175. doi:10.1080/07929978.2015.1060806.

Kumar, M., Kumar, R., Jain, V., and Jain, S. 2018. Differential behavior of the antioxidant system in response to salinity induced oxidative stress in salt-tolerant and salt-sensitive cultivars of Brassica juncea L. Biocatalysis and Agricultural Biotechnology 13:12-19. https://doi.org/10.1016/j.bcab.2017.11.003.

Liu, M., and Jiang, Y. 2015. Genotypic variation in growth and metabolic responses of perennial ryegrass exposed to short-term waterlogging and submergence stress. Plant Physiology and Biochemistry 95:57-64. https://doi.org/10.1016/j.plaphy.2015.07.008.

Nobre, R.G., Lima, G.S. de, Gheyi, H.R., Soares, L.A.A. dos, e da Silva, A.O. 2014. Crescimento, consumo e eficiência do uso da água pela mamoneira sob estresse salino e nitrogênio. Revista Caatinga 27:148-158.

Oliveira, F.A., Souza Neta, M.L., Silva, R.T., Souza, A.A.T., Oliveira, M.K.T., e Medeiros, J.F. 2013. Desempenho de cultivares de rúcula sob soluções nutritivas com diferentes salinidades. Revista Agroambiente 7(2):170-178. http://dx.doi.org/10.18227/1982-8470ragro.v7i2.940.

Paulus, D., Paulus, E., Nava, G.A., and Moura, C.A. 2012. Growth, water consumption and mineral composition of lettuce grown in hydroponics with saline waters. Revista Ceres 59:110-117. doi:10.1590/S0034-737X2012000100016.

Richards, L.A. 1954. Diagnosis and improvement of saline and alkali soils. United States Salinity Laboratory, USA Department of Agriculture, Washington DC., USA.

Rossatto, T., Amaral, M.N., Benitez. L.C., Vighi, I.L., Braga, E.J.B., Magalhães Júnior, A.M., et al. 2017. Gene expression and activity of antioxidant enzymes in rice plants, cv. BRS AG, under saline stress. Physiology and Molecular Biology of Plants 23(4):865-875. doi:10.1007/s12298-017-0467-2.

Shahid, M., Ahmed, B., Zaidi, A., and Khan, M.S. 2018. Toxicity of fungicides to Pisum sativum: a study of oxidative damage, growth suppression, cellular death and morpho-anatomical changes. Royal Society of Chemistry Advances 8:38483-38498. doi:10.1039/C8RA03923B.

Silva, P.F., Cavalcante, V.S., Santos, J.C.C., Costa, E.S., e Barbora, J.T.V. 2014. Análise quantitativa de cebolinha irrigada com água salina. Comunicata Scientiae 5:241-251. https://doi.org/10.14295/cs.v5i3.512.

Silva, A.A.R.D., Lima, G.S.D., Azevedo, C.A.V.D., Gheyi, H.R., Souza, L.D.P., and Veloso, L.L.D.S.A. 2019. Gas exchanges and growth of passion fruit seedlings under salt stress and hydrogen peroxide. Pesquisa Agropecuária Tropical 49:1-12. doi:10.1590/1983-40632019v4955671.

Silva Júnior, F.J., Santos Júnior, J.A., Dias, N., Gheyi, H.R., Rivera, R., Da Silva, G., et al. 2019. Green onion production under strategies of replacement and frequencies of circulation of brackish nutritive solutions. Bioscience Journal 35:796-805. doi:10.14393/BJ-v35n3a2019-41956.

Simões, A.C., Alves, G.K.E.B., Silva, N.M., Ferreira, R.L.F., e Araújo Neto, S.E. 2016. Densidade de plantio e método de colheita de cebolinha orgânica. Agropecuária Científica no Semiárido 12:93-99. doi:10.30969/acsa.v12i1.744.

Sun, Y., Wang, H., Liu, S., and Peng, X. 2016. Exogenous application of hydrogen peroxide relieves water stress in cucumber seedlings. South African Journal of Botany 106:23-28. doi:10.1016/j.sajb.2016.05.008.

Taiz, L., Zeiger, E., Moller, I.M., e Murphy, A. 2017. Fisiologia e desenvolvimento vegetal. ARTMED, Porto Alegre, Brasil.

Tayebi-Meigooni, A., Awang, Y., Biggs, A.R., and Ghasemzadeh, A. 2019. Salt induced changes in growth and damage avoidance mechanisms of hydroponically grown Chinese kale (Brassica alboglabra L.) Springer Nature 49:99-105. doi:10.1007/978-3-030-04417-6_8.

Velikova, V., Yordanov, I., and Edreva, A. 2000. Oxidative stress and some antioxidant systems in acid rain-treated bean plants: Protective role of exogenous polyamines. Plant Science 151:59-66. doi:10.1016/S0168-9452(99)00197-1. 